\title{
INTERACTIONS BETWEEN FIRE AND SPRUCE BEETLES IN A SUBALPINE ROCKY MOUNTAIN FOREST LANDSCAPE
}

\author{
Peter Bebi, ${ }^{1,2,3}$ Dominik Kulakowski, ${ }^{1}$ And Thomas T. Veblen ${ }^{1}$ \\ ${ }^{1}$ Department of Geography, University of Colorado, Campus Box 260, Boulder, Colorado 80309 USA \\ ${ }^{2}$ Division "Alpine Environment," Swiss Federal Institute for Snow and Avalanche Research SLF, \\ CH-7260 Davos, Switzerland
}

\begin{abstract}
Interactions between natural disturbances are widely recognized as important determinants of vegetation patterns in forested landscapes but have only rarely been investigated quantitatively. In a subalpine forest landscape in northwestern Colorado, we quantified spatial associations of fire and spruce beetle (Dendroctonus ruPpennis) outbreaks over more than a century and developed a multivariate logistic model of probability of occurrence of spruce beetle outbreaks. The study area, an $\sim 2800 \mathrm{~km}^{2}$ landscape in White River National Forest, was affected by severe widespread fires around 1879 and by a spruce beetle outbreak in the 1940 s, which affected most of the forests that were dominated by Picea engelmannii (Engelmann spruce) and Abies lasiocarpa (subalpine fir). The boundaries of the fires ca. 1879 and of the 1940s spruce beetle outbreaks were digitized based on an 1898 vegetation map and modern aerial photograph interpretation, and overlaid in a Geographic Information System. The areas disturbed by the ca. 1879 fires and the 1940 s beetle outbreak were also overlaid with 303 fires recorded after 1950 as well as with topographic and forest structural variables.

Forests that had burned in 1879 were less affected by the 1940s outbreak than older stands. On the other hand, areas affected by the 1940s spruce beetle outbreak showed no higher susceptibility to subsequent fires. A multivariate logistic model indicated that, although fire history had the greatest effect on stand susceptibility to spruce beetle outbreak, dominance of neighboring stands by spruce as well as elevation were also important predictors of outbreaks. Predictive modeling of spatial interactions between fire and spruce beetle disturbances needs to consider the high degree of variability in the nature of these interactions related to contingencies such as time since last major disturbance, topographic position, and weather during windows of potential interaction.
\end{abstract}

Key words: Abies lasiocarpa; aerial photographs; Dendroctonus rufipennis; disturbance, largescale; forest Pre; historical map; modeling, GIS; Picea engelmannii.

\section{INTRODUCTION}

Large infrequent disturbances are ecologically important because they often become the dominant factor structuring an ecosystem, and may create long ecological legacies (Turner and Dale 1998). Subsequent ecological processes are strongly influenced by climatic and topographic factors (e.g., Romme and Knight 1981, Callaway and Davis 1993, del Moral and Bliss 1993, Boose et al. 1994), and may also be determined by contingencies such as the spatial arrangement of survivors, timing of availability of propagules, or barriers to the spread of disturbance (Turner et al. 1998). Consequently, it is often difficult to predict the effects of these large disturbances on subsequent ecological processes, including the probability of future disturbance. The modeling of such interactions often requires spatially explicit data sets, which rarely are available (Baker 1999). Thus it is not surprising that interactions between different disturbance types have only rarely been

\footnotetext{
${ }^{3}$ E-mail: bebi@slf.ch
}

quantitatively investigated (Malanson and Butler 1984, Veblen et al. 1994, Wermelinger et al. 1999, Radeloff et al. 2000, Kulakowski and Veblen 2002).

In the subalpine zone of Rocky Mountain coniferous forests, disturbances such as fire, blowdown, and insect outbreaks create mosaics of stands of varying structure and composition (Peet 2000). Fire is often considered the most important form of disturbance in the Rocky Mountain landscape (Clements 1910, Habeck and Mutch 1973, Peet 2000) and consequently, there have been numerous investigations of the ecological impacts of fire in these forests (see reviews in Peet 2000 and Veblen 2000). However, disturbance by spruce beetle (Dendroctonus ruppennis Kirby) outbreaks is also widespread in the southern Rocky Mountains, and in some areas spruce beetle outbreaks may be as ecologically significant as fire (Schmid and Frye 1977, Baker and Veblen 1990, Veblen et al. 1991).

Fire and insect disturbances have been shown to interact synergistically to affect forest succession, nutrient cycling, floristic composition, and species diversity (McCullough et al. 1998). In the case of spruce beetle outbreaks, early in the 20th century it was suggested 


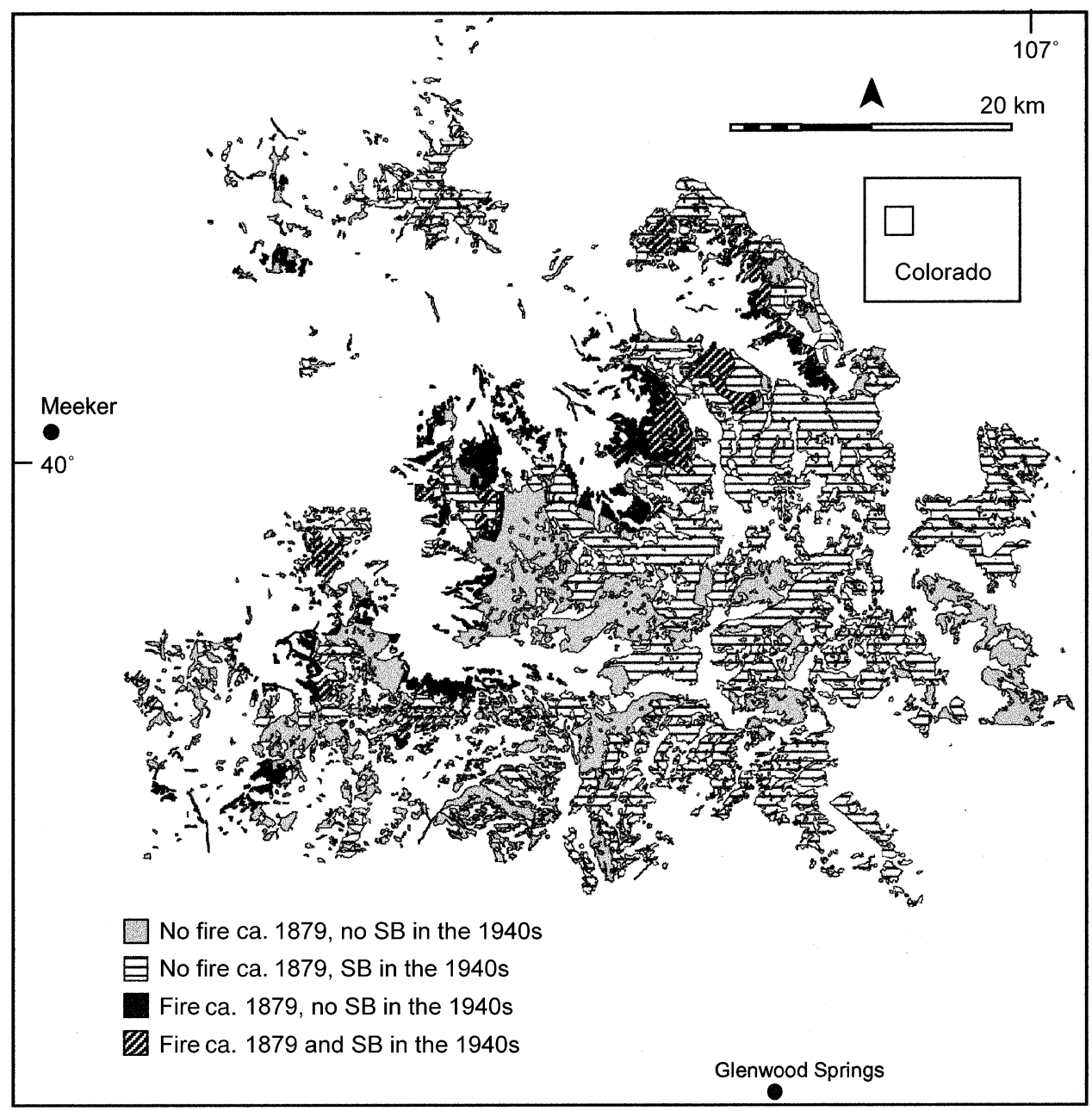

FIG. 1. Study area showing areas affected by the ca. 1879 fires (from Sudworth's 1898 map) and by the 1940s spruce beetle (SB) outbreaks.

that mortality caused by beetle outbreaks increased subsequent fire occurrence (Hopkins 1909). The belief that insect-caused tree mortality increases the likelihood of subsequent fire has been supported by three principal arguments: (1) snags are potential lightning rods that may increase the frequency of lightning ignitions (Barrows 1951, Schmid and Hinds 1974); (2) dead needles retained on the trees dramatically increase the total amount and vertical continuity of fine, dry fuels (Brown 1975, Knight 1987); and (3) beetle-caused tree mortality opens up the main canopy so that seasonal desiccation of understory fuels is intensified (Brown 1975, Furyaev et al. 1983). Conversely, fires also affect the susceptibility of a stand to subsequent attack by spruce beetles. Since beetles primarily attack mature trees (Schmid and Hinds 1974), stands that have recently originated after a crown fire may not be attacked even when neighboring older stands are heavily infested (Veblen et al. 1994, Schmid and Mata 1996). However, there is little quantitative information on these potential fire and beetle interactions, or on how these interactions may be influ- enced by factors such as topography and stand structure. We examined these interactions in an $\sim 2800 \mathrm{~km}^{2}$ study area in the White River National Forest in northwestern Colorado (Fig. 1). This area was chosen for study because it was affected by an extensive and intense fire in about 1879 , which was mapped by G. B. Sudworth in 1898 (Sudworth 1900), and by a major outbreak of spruce beetles in the 1940s (Schmid and Frye 1977). Furthermore, the area has not been affected by large recent (i.e., post 1908) fires (Schmid and Frye 1977; USDA Forest Service, Glenwood Springs, Colorado, USA, unpublished data) that would have obscured evidence of the disturbance events in 1879 and the 1940s. While fire suppression may have prevented some ignitions from spreading into large fires, it would not have decreased the density of observed fires below natural levels since the 1940 s.

We use a combination of Sudworth's 1898 map of areas burned in 1879 , modern aerial photographic interpretation of evidence of disturbance history, modern Forest Service maps of forest types, fires, and spruce 
beetle outbreaks, and GIS modeling to address the following three questions: (1) Were young post-fire stands that originated after the ca. 1879 fires either not affected or less severely affected by the 1940s spruce beetle outbreak than were older stands? (2) Have forests affected by the 1940 s spruce beetle outbreak experienced higher densities of subsequent fire than comparable forests unaffected by the beetle outbreak? (3) How are these interactions influenced by topographic and stand structural factors?

\section{Methods}

\section{Study area and databases}

The study area (Fig. 1) is located in the Flat Tops Wilderness and adjacent areas of the White River Plateau, which is a basaltic plateau at $\sim 2000-3500 \mathrm{~m}$ elevation in northwestern Colorado. At Marvine Ranch ( $2380 \mathrm{~m}$ above sea level) in the central part of the study area, mean January temperature is $-6.8^{\circ} \mathrm{C}$, mean July temperature is $11.4^{\circ} \mathrm{C}$, and annual precipitation is 668 $\mathrm{mm}$. With the exception of the highest areas (alpine meadows) and some of the lowest elevations (agricultural land, brushland), subalpine and upper montane forests dominate the landscape. Picea engelmannii (Parry) Engelm. (Engelmann spruce) and Abies lasiocarpa (Hook.) Nutt (subalpine fir) codominate the spruce-fir forest type that is the most extensive forest type of the subalpine zone (i.e., above $\sim 2800 \mathrm{~m}$ a.s.1.). Patches of Populus tremuloides Michx. (quaking aspen) occur in all elevation zones and together with Pinus contorta Dougl. var. latifolia Engelm. (lodgepole pine) and Pseudotsuga menziesii (Mirb.) Franco (Douglas-fir) dominate the forests of the upper montane zone (i.e., below $2800 \mathrm{~m}$ a.s.1.).

In 1898 George B. Sudworth mapped the extent of recent forest burning (Sudworth 1900). Sudworth used the ages of young trees established on the burns to estimate the dates of the most extensive burning as occurring ca. 1879 and ca. 1887, but he also noted that significant areas burned through the $1890 \mathrm{~s}$. The ca. 1879 fire date is also supported by an 1879 letter, written by a local mining official to the General Land Office in Washington, D.C., USA, which reported vast areas burned in that year (USDA Forest Service 1972). It is also consistent with fire scar dates and maximum tree ages in post-fire cohorts in the study area dating to ca. 1880. (Kulakowski 2002). Although the current study refers to "the ca. 1879 fires" because Sudworth's map describes the fires as occurring "around 1879," it is likely that these burns occurred in at least several major fire years over an $\sim 20$-yr period.

In constructing his vegetation map, Sudworth (1900) estimated distances from vegetation boundaries to landscape features and produced a detailed map of the study area in a geographic coordinate system overlaid with 100 -ft $(\sim 30.48 \mathrm{~m})$ contour lines. Beside the extent of the ca. 1879 fires, Sudworth also delineated the veg- etation categories of "grassland," "forested area" (including dominant tree species), "brushland," "alpine meadows," and "agricultural land." We digitized the extent of the ca. 1879 fires into a GIS and georectified it with the aid of 40 control points (e.g., river forks, mountain peaks, settlements, and lakes). The resulting mean positional error, calculated as the output of the georectification process, was $70 \mathrm{~m}$ (range of $0-138 \mathrm{~m}$ ). We used digital raster maps and 20 -m contour lines as background coverages to correct the georectification in a rubber sheeting algorithm (ESRI 2000). To further improve the accuracy of the fire map, a buffer of 100 $\mathrm{m}$ to each side of each polygon boundary was eliminated before any analyses were performed. This resulted in an underestimate of the area of forest burned in 1879 , but also reduced the risk of confusing burned and unburned forest.

Following an intense windstorm in 1939 a large spruce beetle outbreak affected most of the spruce-fir cover type in northwestern Colorado in the 1940s. The outbreak was centered on White River National Forest where it killed $>90 \%$ of the spruce (Hinds et al. 1965, Schmid and Hinds 1974). Forest Service sketch maps of the extent of the beetle outbreak were available, but were too generalized for quantitative analyses. Consequently, we used the earliest available aerial photographs (IR-1984, 1:50 000 and color-1971, 1:10000) to map the extent and severity of the 1940s spruce beetle outbreak in the area delineated as spruce-fir forest (total area of $695 \mathrm{~km}^{2}$ ). Mapping criteria were percentage of standing dead trees in the overstory, frequency of $\log$ s on the ground, and abundance of subcanopy trees (i.e., $<20 \mathrm{~cm}$ diameter at breast height). In the field, we visited 54 polygons (i.e., stands of homogeneous forest type and structure as identified on aerial photographs) within the study area to calibrate and verify the aerial photo interpretation. The 54 polygons (total area $\cong 4600$ ha) are located in the valley of the North Fork of the White River and include both post-fire stands and old-growth forests with different degrees of spruce beetle activity in the late 1940s. Similar mapped data from a study of disturbance history and stand structures in an $\sim 35 \mathrm{~km}^{2}$ area centered on Marvine Lakes in the study area (Veblen et al. 1994) were also used for verification of our broad-scale aerial photographic interpretation.

Based on the field observations in the 54 polygons, we developed a protocol for interpreting different disturbance classes of spruce-fir stands from visual stereoscopic examination of the aerial photographs. Surface area (crown cover) of standing dead trees and logs were estimated in $10 \%$ classes of the ground surface area. Stands significantly affected by spruce beetle attack were defined as stands in which $>30 \%$ of the canopy trees (standing plus downed) were dead. All such stands also had an abundance of subcanopy trees (i.e., $<20 \mathrm{~cm} \mathrm{dbh}$ ) as is typical of stands that were affected by spruce beetles in the 1940s and 1950s (Veb- 
len et al. 1991). We also identified young ( $\sim 50-120$ yr old) post-fire stands that are characterized by extremely dense and uniform canopies with small crown diameters (Veblen et al. 1994, Bebi et al. 2001).

We used the stand delineation of digital USDA Forest Service Resource Information System (RIS) maps (1993) to transfer the aerial photo interpretation to a georectified database and to add attributes for the different disturbance variables (percent of canopy trees that are standing dead, percent of trees that are downed, structure of young post-fire stands) to each stand. These digital RIS data were also used for information on forest structure and forest composition. Terrain data (slope angle, slope aspect, curvature, and the occurrence of valley bottoms) were derived from a USGS digital elevation model (30-m resolution) with functions in the GRID module of ArcInfo (ESRI 2000). Geographic Information System (GIS) layers (occurrence of spruce beetle and fire according to the 1898 Sudworth map and according to the aerial photo interpretation, topographic variables, forest structural variables) were transformed into the same raster format. The relatively small raster size of $30 \times 30 \mathrm{~m}$ was chosen to avoid smoothing of topographical variables and because of the frequent occurrence of small vegetation patches in the same size range. Forest structural variables used in the RIS database included crown cover classes $(\mathrm{C} 1,0-$ $40 \%$; $\mathrm{C} 2,40-70 \% ; \mathrm{C} 3,70-100 \%)$ and tree diameter classes (D1, dbh $<23 \mathrm{~cm}$; D2, dbh $>23 \mathrm{~cm}$ ). Three hundred and three forest fires within the Flat Tops study area were digitized from Forest Service fire atlas data, covering the period from 1950 to 1990 . More than $95 \%$ of the fires were smaller than 2.1 ha ( 5 acres) and were digitized as point data; larger fires were digitized as polygons. These 13 larger fires had a median size of 12.5 ha and a range of 2.1 to 1330 ha.

\section{Data Analysis and Modeling Approaches}

Effect of the ca. 1879 Pres and other factors on the 1940s spruce beetle outbreak

We stratified the study area into subareas for model development (MD) and for model validation (MV). The MD and MV subareas consisted of 34 nonadjacent 6 $\times 6 \mathrm{~km}$ areas of similar amounts of post-fire as well as spruce beetle affected stands. The effect of spatial autocorrelation was limited by taking a random sample of 867 grid cells in the MD subarea with a minimal distance of $660 \mathrm{~m}$ (lag $=22$ cells) between each grid cell. This minimum lag distance was determined with the help of correlograms of the input variables. The correlogram analyses showed that this lag distance yielded an acceptable level of autocorrelation (Moran's $I$ of $<0.5$ for each variable) while retaining an adequate sample size for representing the entire data set with an error range of $<5 \%$ and a confidence interval of $99 \%$ (Sheskin 1985).
All potential explanatory variables of the $1940 \mathrm{~s}$ spruce beetle outbreak were examined with univariate tests (chi-square contingency tables for binary variables and univariate logistic models for continuous variables). Potential neighborhood effects of explanatory variables on spruce beetle occurrence were checked by performing these tests in square moving windows of different sizes. The side length of these windows ranged from 90 to $1500 \mathrm{~m}$. To find significant variables for multivariate logistic models, we reduced the number of variables by rejecting all variables with a $P$ value $>0.05$ in the univariate tests and with a subsequent backward stepwise elimination process (Hosmer and Lemeshow 1989, MathSoft 1999) until only those variables remained that significantly improved the model. We then tested for their linearity by transforming variable $x_{\mathrm{i}}$ into $x_{\mathrm{i}}^{2}, \log \left(x_{\mathrm{i}}\right)$, and $x_{\mathrm{i}} \log \left(x_{\mathrm{i}}\right)$. We followed the procedure of Brito et al. (1999) for checking for possible interactions between variables, by adding to the model the term $x_{\mathrm{i}} x_{\mathrm{j}}$ where $x_{\mathrm{i}}$ and $x_{\mathrm{j}}$ are two different explanatory variables. However, in no case was the model significantly improved by addition of the interaction term. To investigate scale dependency of the modeling outcomes, we also repeated univariate tests and multivariate logistic models for a complete sample $(n=65000)$ and for a very large lag distance of 1500 $\mathrm{m}(\mathrm{lag}=50$ cells; $n=125)$.

Because model residuals remained spatially autocorrelated at all investigated scales (Moran's statistics; Kaluzny et al. 1997), we also modeled potential spruce beetle outbreaks with an autologistic model approach (Augustin et al. 1996). In contrast to the logistic model, the autologistic model incorporates the remaining spatial autocorrelation of the sampling points by including as an additional explanatory variable the weighted mean of the number of spruce beetle affected grid cells amongst a set of neighbor cells (Augustin et al. 1996).

We evaluated the different multivariate models to predict locations of spruce beetle outbreaks separately for all $30 \times 30 \mathrm{~m}$ grid cells in the subareas for model development (MD) and for model validation (MV). As a measure of the predictive power we used Cohen's $\kappa$ (1960) to calculate the spatial association between predicted and observed spruce beetle outbreak extent. For logistic models we reduced the probability values $(P)$ of spruce beetle outbreak to a binary variable and selected the highest value of all $\kappa$, calculated as a function of different threshold probability values (Guisan et al. 1998). To evaluate the predictive power of the autologistic model, we estimated the presence/absence distribution in unsurveyed grid cells by starting with the prediction of a logistic model and using a Gips sampler (Augustin et al. 1996) to iteratively replace the values of randomly selected grid cells by a new value, calculated from the autologistic model. Thus information on the probability of spruce beetle outbreak in neighboring cells was incorporated. This process continued through all grid cells until convergence. 


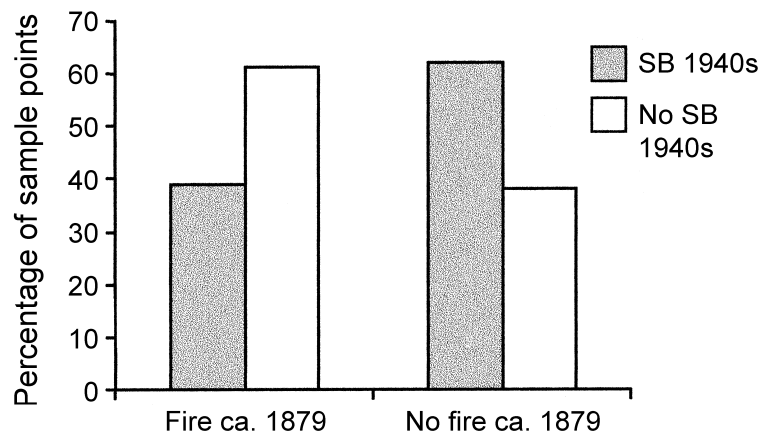

FIG. 2. Percentage of sample points affected (gray bars) and not affected (white bars) by the 1940s spruce beetle (SB) outbreak for areas mapped in 1898 by Sudworth as burned ca. 1879 vs. areas not burned by $1898 ; n=867$. Differences between stands affected and not affected by spruce beetle are statistically significant $(P<0.005$; chi-square contingency table).

\section{Effect of spruce beetle outbreak occurrence and other factors on subsequent Pre density}

We examined habitat (site and vegetation attributes) characteristics of sites affected by fire with sites not burned during the 1950 to 1990 period of the White River National Forest record of fires. Habitat factors included forest structural and topographic factors as well as status as being affected by the ca. 1879 fires and the 1940s spruce beetle outbreak. For each factor we calculated the observed fire density $\left(d_{\text {obs }}\right)$ as the $S_{\mathrm{fi}} /$ $S_{\text {ai }}$, where $S_{\text {fi }}$ is the number of fires and $S_{\text {ai }}$ is the total area of a specific habitat type within the study area. We then compared these observed fire densities $\left(d_{\text {obs }}\right)$ with the expected fire densities $\left(d_{\text {exp }}\right)$ according to the available areas of habitat type and tested for equality of $d_{\text {obs }}$ and $d_{\exp }$ (chi-square goodness-of-fit test with Yates' correction for $1 \mathrm{df}$ ).

\section{RESULTS}

\section{Effect of the ca. 1879 Pres and other factors on the} 1940s spruce beetle outbreak

The ca. 1879 fires mapped by Sudworth in 1898 affected 9900 ha or $15 \%$ of the $695-\mathrm{km}^{2}$ area of the spruce-fir cover type examined in this study. The area affected by the ca. 1879 fires overlapped to only a small extent (5.5\% of the total study area) with the extensive spruce beetle outbreak of the 1940s (Fig. 1), which we mapped on $58 \%$ of the examined spruce-fir stands. Young post-fire stands resulting from the ca. 1879 fires were either not affected or were less severely affected by the 1940 s spruce beetle outbreak than areas not burned in 1879 (Fig. 2). The effect of post-fire stands in diminishing subsequent spruce beetle activity was highly significant when all photo-interpreted post-fire stands were included (chi-square $=167.2, P<0.001$ ), and also when Sudworth's 1898 map was used as the basis for determining post-fire origin (chi-square = 85.1, $P<0.001)$. Overlapping areas of both distur- bances were mostly at lower elevations, on northerly aspects, and on less steep slopes. Occurrence of subsequent spruce beetle disturbance was higher in stands at higher elevation (univariate logistic model; $P<$ 0.001 ) and in stands with a high percentage of sprucefir stands within a $900 \times 900 \mathrm{~m}$ neighborhood (univariate logistic model; $P<0.001)$. In a multivariate logistic model (Eq. 1) after stepwise elimination of the least significant factors, only the occurrence of postfire stands (pf), elevation $(h)$, and amount of sprucefir in the neighborhood $\left(\mathrm{PE}_{\mathrm{n} 900}\right)$ remained in the model as explanatory variables for the probability of occurrence of spruce beetle outbreaks $\left(P_{\mathrm{SB}}\right)$ :

$$
\begin{aligned}
& \ln P_{\mathrm{SB}} /\left(1-P_{\mathrm{SB}}\right) \\
& \quad=-7.8+0.0025 h-1.53 \mathrm{pf}+1.278 \mathrm{PE}_{\mathrm{n} 900} .
\end{aligned}
$$

This model had the highest kappa value of all the logistic models developed in the subarea for model development (MD; $\kappa=0.43$ ) and for model validation $(\mathrm{MV} ; \kappa=0.31)$. Compared to the logistic model, the same explanatory variables were retained in the autologistic model. The additional autologistic term had the effect that significant autocorrelation in the model residuals disappeared, but the predictive power of the model in the MV subarea ( $\kappa=0.32$ ) was only slightly improved compared to the logistic model.

For both the multivariate models and univariate tests, $P$ values decreased when lag size was very small and increased for large lag sizes. However, with the exception of $\mathrm{PE}_{\mathrm{n} 900}$ (univariate logistic model; $P=0.1$ ) all significances were retained even when the minimal distance between the sampling cells was increased to $1500 \mathrm{~m}(\mathrm{lag}=50$ cells; $n=125)$.

\section{Effect of the 1940s spruce beetle outbreak and other factors on subsequent Pre density}

In the $695 \mathrm{~km}^{2}$ area of spruce-fir forests examined within the Flat Tops study area, 159 fires or 3.8 fires/ yr were recorded between 1950 and 1990 (Fig. 3). Fire density in this time period was significantly lower in areas affected by the 1940 s spruce beetle outbreak than in areas not affected by the outbreak (Fig. 4; Table 1). However, fire densities in beetle affected stands were not significantly lower when only lightning caused fires were considered $(n=44$, chi-square $=3.1, P=0.08$ ); and when only elevations above $3000 \mathrm{~m}$ a.s.l. were considered there were no differences in fire frequencies between areas affected and not affected by the spruce beetle outbreak ( $n=71$, chi-square $=0.3, P=0.59$ ). Thus a reduction of fire density in areas affected by the 1940s spruce beetle outbreak was only observed for lower elevations (areas $<3000 \mathrm{~m}$ a.s.1.; $n=88$, chi-square $=6.2, P=0.01)$ where human caused fires were more frequent. Although the analysis period started in 1950 (after the spruce beetle outbreak subsided), there also was no increase in fire occurrence in the late 1940s when the recently killed trees would still have 


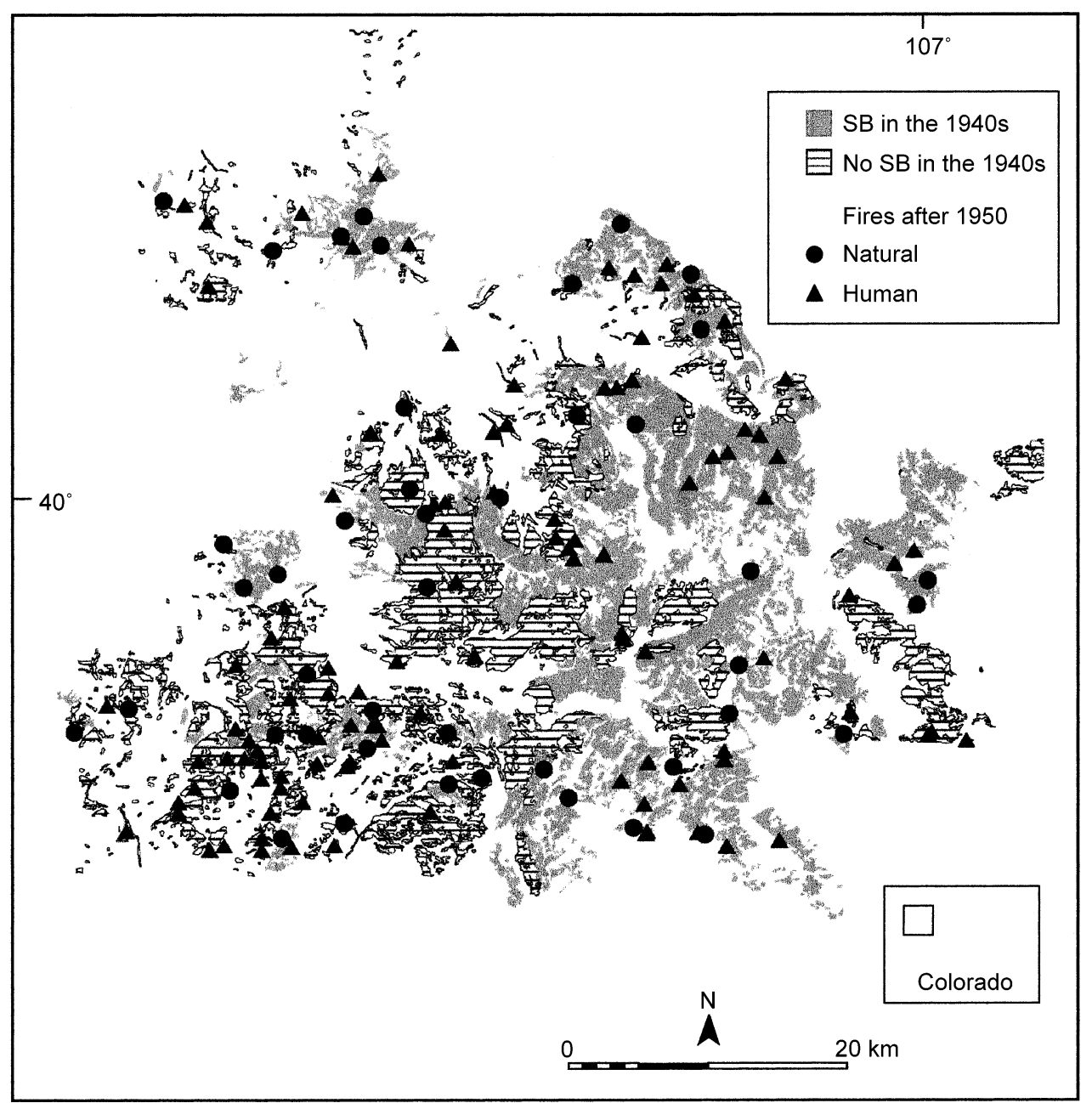

FIG. 3. Fires that occurred between 1950 and 1990 in spruce-fir stands (from the USDA Forest Service fire atlas) overlapped with the extent of the 1940s spruce beetle outbreak (aerial photographic interpretation) in the study area.

retained large amounts of fine fuels. From 1948 through 1950 , only three fires were recorded in the study area and none of these were stands affected by the spruce beetle outbreak (USDA Forest Service, Glenwood Springs, Colorado, USA, unpublished data).

\section{DISCUSSION}

The combined use of an 1898 vegetation map and modern aerial photographic interpretation (verified by field observations) permitted the quantification of interactions of fire and spruce beetle outbreak over a forested area of $695 \mathrm{~km}^{2}$. The results at this broad scale of analysis are consistent with the findings at a watershed scale $\left(35 \mathrm{~km}^{2}\right)$ that crown fire reduces the subsequent occurrence of spruce beetle outbreak (Veblen et al. 1994, Kulakowski 2002). In contrast, the results of the current study do not support the often-suggested increase in fire occurrence expected to follow spruce beetle outbreaks (Hopkins 1909, McCullough et al. 1998).

At the coarse spatial resolution provided by the 1898 Sudworth map, there is a strong tendency for the area of spruce-fir forest affected by the ca. 1879 fires not to be affected by the 1940 s spruce beetle outbreak (Figs. 1 and 2). Although the pattern of reduced spruce beetle outbreak shown for the stands affected by the

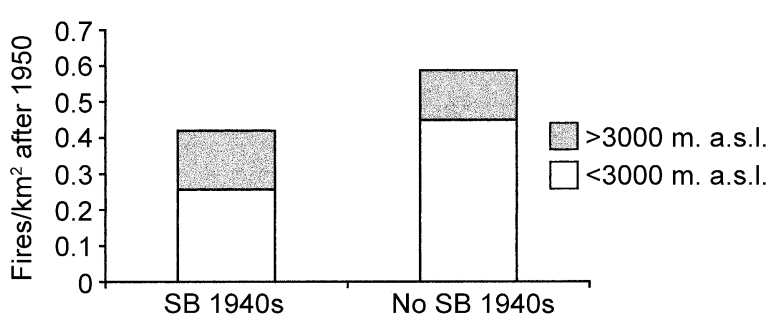

FIG. 4. Fire frequencies (1950-1990) in areas affected by the spruce beetle outbreak of the 1940s compared to fire frequencies in areas not affected by the spruce beetle outbreak; $n=303$. Fire density differences between beetle affected and unaffected stands are significant for points below $3000 \mathrm{~m}$ and for all elevations $(P=0.003$ and 0.01 , respectively; chisquare contingency table); but are not significant for points above $3000 \mathrm{~m}(P=0.6)$. 
TABLE 1. Density of fires (no./ $\mathrm{km}^{2}$ ) following the 1940 s spruce beetle outbreak (1950-1990) in areas of different biotic and abiotic characteristics analyzed for five data sets defined by forest type, fire origin, and elevational zone.

\begin{tabular}{|c|c|c|c|c|c|c|}
\hline & \multicolumn{2}{|c|}{ Spruce beetles in $1940 \mathrm{~s}$} & \multicolumn{2}{|c|}{ Crown density (\%) } & \multicolumn{2}{|c|}{ Mean diameter $(\mathrm{cm})$} \\
\hline & Outbreak $\dagger$ & No outbreak & $<70$ & $\geq 70$ & $<23$ & $\geq 23$ \\
\hline \multicolumn{7}{|l|}{ Spruce-fir, natural fires } \\
\hline All sites (44 fires/695 km²) & $0.05(\mathrm{NS})$ & 0.08 (NS) & $0.08(\mathrm{NS})$ & $0.04(\mathrm{NS})$ & 0.07 (Ns) & 0.04 ( NS) \\
\hline \multicolumn{7}{|l|}{ Spruce-fir, all causes } \\
\hline All sites (159 fires $/ 695 \mathrm{~km}^{2}$ ) & $0.18 * *$ & $0.29 * *$ & $0.26 *$ & $0.18 *$ & $0.32 * * *$ & $0.14 * * *$ \\
\hline Sites $<3000 \mathrm{~m}\left(88\right.$ fires $\left./ 236 \mathrm{~km}^{2}\right)$ & $0.26 *$ & $0.45^{*}$ & $0.55 * * *$ & $0.23 * * *$ & $0.51 * * *$ & $0.24 * * *$ \\
\hline Sites $\geq 3000 \mathrm{~m}\left(71\right.$ fires $\left./ 459 \mathrm{~km}^{2}\right)$ & $0.16(\mathrm{NS})$ & 0.14 (NS) & 0.18 (NS) & $0.10 *$ & $0.23 * * *$ & $0.07 * * *$ \\
\hline \multicolumn{7}{|l|}{ All cover types, all causes } \\
\hline All sites (303 fires/2810 km²) & 0.10 (NS) & 0.11 (NS) & 0.11 (NS) & 0.11 (NS) & 0.10 (NS) & 0.11 (NS) \\
\hline
\end{tabular}

Note: Departures from observed and expected frequencies of spatial associations were tested with a chi-square test for homogeneity (with Yates' correction for $1 \mathrm{df}$ ).

$* P<0.05 ; * * P<0.01 ; * * * P<0.001$; NS not significant

$\dagger$ Areas affected by the 1940 s spruce beetle outbreak.

\$ Includes azimuths from 135 to 225 .

$\S$ Slopes with positive curvature at each grid cell.

ca. 1879 fires is robust, the limitations of the accuracy of Sudworth's 1898 map must be considered. Historical maps generally lack the topographic and classificatory accuracy of modern maps but still can provide critical information for understanding coarse-scale vegetation changes (Mead 1982, Östlund et al. 1997, Skanes and Bunce 1997, Kitzberger and Veblen 1999). In comparison with modern topographic maps, Sudworth's 1898 map is highly accurate as indicated by (1) locational agreement of many topographic details (i.e., ridges, summits, and water courses) with modern topographic maps of the study area, and (2) satisfactory georectification as tested by global positioning system readings at field sampling points.

Reduced severity of spruce beetle attack in young post-fire stands is consistent with knowledge of spruce beetle behavior (Schmid and Frye 1977). Although during severe epidemics spruce beetle may attack standing trees of all sizes, typically trees $>50 \mathrm{~cm}$ dbh are strongly preferred over smaller trees. In a stand rating system for spruce beetle susceptibility, stands of $\sim 30 \mathrm{~cm} \mathrm{dbh}$ trees are considered to have medium susceptibility and stands of $>40 \mathrm{~cm}$ dbh trees have high susceptibility (Schmid and Frye 1976). The stands burned in ca. 1879 would have been dominated by trees younger than 68 yr old at the peak of the 1940s outbreak and most of these would have been too small to be in the high susceptibility size class according to the classification of Schmid and Frye (1976). Nevertheless, 4000 ha (6\% of the study area) of the area burned in 1879 fires also were affected by the 1940 s spruce beetle outbreak. We suggest two possible explanations for this overlap: (1) Due to favorable site conditions, more rapid growth of spruce may have resulted in larger diameter trees and increased susceptibility to spruce beetle attack; and/or (2) some areas mapped by Sudworth as postfire stands may have only partially burned, leaving large remnant trees that supported the beetle outbreak. Based on our field observations of beetle outbreaks in stands less severely burned by the ca. 1879 fires and on the locations of some post-fire but beetle-affected stands on apparently more productive sites, we believe that both explanations are valid.

Although the status of a stand as burned or unburned by the ca. 1879 fires had the greatest effect on stand susceptibility to the spruce beetle outbreak of the 1940s, the multivariate logistic model (Eq. 1) indicates that elevation and crown density of spruce in neighboring stands are also important predictors of spruce beetle outbreak. Greater spruce beetle activity in the 1940 s at higher elevation can partly be explained by the fact that lower elevations were more affected by the ca. 1879 fires (Sudworth 1900), and consequently high elevation spruce-fir forests were older and contained more large diameter trees. The strong association with percentage of the spruce-fir forest type in a 900 $\mathrm{m}$ neighborhood $\left(\mathrm{PE}_{\mathrm{n} 900}\right)$ around the target point indicates that a severe spruce beetle outbreak such as the 1940 s event spreads to almost all adjacent spruce stands, but the spread of the outbreak is significantly affected by nonhost habitats such as meadows, lakes, or other forest types. Although spruce beetles are known to fly distances of $>10 \mathrm{~km}$ (Schmid and Frye 1977) the greater impact within a $900 \mathrm{~m}$ moving window, compared to smaller and larger windows, indicates that nonhost habitat breaks at this scale are significant influences on spruce beetle outbreak severity.

Structure type and the location of stands in valley bottoms (i.e., upwardly concave slopes with a mean curvature of $\geq 0.05$ within a $300 \times 300$ m neighborhood), which are generally regarded as key factors in determining severity of spruce beetle outbreaks (Schmid and Frye 1977, Reynolds and Holsten 1994), were less critical in our study. This discrepancy, however, should not be over emphasized because stand structural data (Forest Service RIS) and our aerial photographic interpretation are based on photographs taken several decades after the outbreak. Consequently, for 
TABle 1. Extended.

\begin{tabular}{|c|c|c|c|c|c|}
\hline \multicolumn{2}{|c|}{ Elevation (m a.s.1.) } & \multicolumn{2}{|c|}{ Exposition } & \multicolumn{2}{|c|}{ Slopes } \\
\hline$<3000$ & $\geq 3000$ & South $\neq$ & North & Convex & Concave \\
\hline 0.08 (NS) & $0.05(\mathrm{NS})$ & $0.08^{*}$ & $0.02 * * *$ & $0.08(\mathrm{NS})$ & $0.05(\mathrm{NS})$ \\
\hline $\begin{array}{l}0.37 * * * \\
0.37 \\
\quad \ldots\end{array}$ & $\begin{array}{c}0.15^{* * * *} \\
\ldots \\
0.15\end{array}$ & $\begin{array}{l}0.36 * * * \\
0.61 * * * \\
0.28^{* * *}\end{array}$ & $\begin{array}{l}0.11 * * * \\
0.17 * * * \\
0.06 * * *\end{array}$ & $\begin{array}{l}0.26 \text { (NS) } \\
0.46^{*} \\
0.17 \text { (NS) }\end{array}$ & $\begin{array}{l}0.20 \text { (NS) } \\
0.29 * \\
0.13 \text { (Ns) }\end{array}$ \\
\hline $0.13 *$ & $0.08 *$ & $0.12 *$ & $0.08 *$ & $0.12 *$ & $0.09 *$ \\
\hline
\end{tabular}

stands that suffered high levels of tree mortality in the 1940 s, the classification of crown density and tree diameter sizes may not have detected subtle differences in stand structure that may have existed at the time of the outbreak. Therefore, crown density and diameters may be underestimated for affected stands that had many standing dead and downed trees. Also, severity of the outbreak might have been underestimated for valley bottoms, where growth was accelerated compared to drier sites (Romme and Knight 1981).

Following the widespread 1940s spruce beetle outbreak, there was no increase in fire density in affected stands compared to unaffected stands (Figs. 3 and 4; Table 1). This does not support the long-standing notion (Hopkins 1909) that insect-caused mortality increases fire risk, which is also an important consideration in modern forest management following insect outbreaks (Schmid and Hinds 1974). Our analysis is based on the variable "fire density" and thus focuses on the number of observed fires rather than size or severity of fires. However, the variable of fire density may be influenced by fire size because of the greater probability that larger fires will be reported before being extinguished naturally. Our finding that there was no statistically significant increase in lightning-ignited fire density in stands affected by the 1940s beetle outbreak in comparison with unaffected stands (Table 1) is most relevant to expectations that snags are potential lightning rods that increase the frequency of ignitions (Barrows 1951, Schmid and Hinds 1974). Our results also indicate that despite the increase in dead fine fuels resulting from the 1940 s beetle outbreak, fire density did not increase. However, as noted by Knight (1987), the increase in fire risk may only last $2-3$ yr because of the rapid fall and decay of the dead needles. Although this increase in fine fuels may in fact create a significantly higher fire probability, the weather conditions conducive to extensive fire spread in sprucefir forests are relatively infrequent (Veblen 2000). Thus, unless a beetle outbreak is followed by extreme drought within two or three years the increase in fire risk due to dead needles on standing trees is unlikely to result in widespread fire. The third argument, that greater understory desiccation results from the open canopy, is not entirely consistent with the proliferation of mesic understory herbs that follows canopy mortality in these forests (Reid 1989). Perhaps in years of extreme drought increased desiccation of the understory fuels is important, but in a year of average moisture availability the understories in the spruce-fir stands affected by beetle outbreak are relatively mesic.

Although no increase in fire density followed the 1940 s spruce beetle outbreak, potentially the large quantity of standing dead fuels might be expected to contribute to more intense and widespread fire in the affected stands, especially in comparison with younger stands lacking large numbers of large, standing dead trees (Despain and Sellers 1977). However, contingencies of fire-promoting weather, ignition sources, and fire suppression activities may determine whether such potential interactions are realized. For example, during the second half of the 20th century either weather conditions or suppression activities may have prevented large fires from developing in the study area. Potentially, the intensity and spread of the ca. 1879 fires were aided by exceptionally favorable fuel conditions and weather as well as by human ignition sources. The widespread fires of the late 1800 s in our study area followed major spruce beetle outbreaks in the mid 19th century that were comparable in extent and intensity to the 1940s outbreak (Baker and Veblen 1990, Veblen et al. 1991). These outbreaks would have left abundant dead fuels for many decades. The ca. 1879 fires also coincided with severe droughts in the Colorado Rockies in the 1880s (see Cook et al. 1998 [available online] $)^{4}$ during which large areas of subalpine forest burned in our study area and nearby areas of subalpine forest (Kipfmueller and Baker 2000, Sibold 2001, Kulakowski and Veblen 2002). Furthermore, white settlers reported that vast areas were burned in our study area in 1879 and in the 1880 s by fires which were intentionally set by the Ute inhabitants who were forced out of the region ca. 1887 (Sudworth 1900; USDA Forest Service 1972). Given the high frequency of lightning-

${ }^{4}$ URL: 〈http://www.ngdc.noaa.gov/paleo/-drought.html〉 
ignited fires in the region, however, the origins of these fires cannot be determined with certainty.

Our data suggest that interactions between fire and spruce beetle outbreaks are highly variable spatially in relation to topographic variables. Thus the time period for which a preceding fire reduces probability of subsequent spruce beetle outbreaks may vary between 50 and $100 \mathrm{yr}$ depending on topographic position. As the post-fire spruce-fir forests continue to develop into stands of higher basal area, their susceptibility to spruce beetles is expected to greatly increase (Schmid and Frye 1977, Reynolds and Holsten 1994). Potentially, after $\sim 150-200 \mathrm{yr}$ of stand development these post-fire stands will have larger basal areas of spruce and therefore greater susceptibility to spruce beetles than stands where the large spruce were killed in the 1940s.

Although there is increasing appreciation of how disturbance regimes shape landscapes and of how disturbances such as fire and insect outbreak interact, the occurrence of certain disturbances is only predictable under narrowly defined conditions of site and weather (Baker 1999). Conditions that increase the probability of occurrence of a certain disturbance, such as increased fire risk due to the dead needles on beetle-killed trees, may change within just a few years. Furthermore, the potential for disturbance interactions such as fire following beetle outbreak may be highly dependent on coincidence with extreme weather conditions. Analogously, amounts of tree mortality associated with severe earthquakes have been shown to vary with weather conditions at the time of the earthquake (Kitzberger et al. 1995). Indeed, for subalpine forests in the southern Canadian Rockies, it has been argued that fuel loads are unimportant relative to fire weather in creating conditions for widespread burning (Bessie and Johnson 1995). Likewise, in the case of the 1988 Yellowstone fires, fuel loads that under less extreme weather conditions had been a major influence on fire spread were relatively unimportant under conditions of extreme fire weather (Romme and Despain 1989, Turner et al. 1994).

The combined use of field-verified aerial photographic interpretation, historical documents, and multivariate GIS analysis is an effective strategy for disentangling disturbance interactions at a broad spatial scale in a topographically diverse landscape. Such an approach allows incorporation of a wide range of specific biotic and abiotic site conditions so that these contingencies can be evaluated in developing an understanding of the relative importance of different factors that determine a complex pattern of disturbance interaction. This broadscale approach is most effective when it is complemented by studies conducted at stand scales that intensively examine the nature of disturbance interactions for particular site conditions (e.g., Veblen et al. 1994, Kulakowski 2002). Through such a multi-scale approach it is possible to improve our understanding of the spatial variability of disturbance interactions.

\section{ACKNOWLEDGMENTS}

Support for this study was provided by the Swiss National Science Foundation (SNF), the National Science Foundation of the USA, and by the USDA Forest Service, Rocky Mountain Region. For field assistance we thank B. Woods, S. Padgett, and L. Gregory. For helpful comments on the manuscript we thank W. L. Baker, F. W. Davis, B. Algöhwer, and two anonymous reviewers.

\section{Literature Cited}

Augustin, N. H., M. A. Mugglestone, and S. T. Buckland. 1996. An autologistic model for the spatial distribution of wildlife. Journal of Applied Ecology 33:339-347.

Baker, W. L. 1999. Spatial simulation of the effects of human and natural disturbance regimes on landscape structure. Pages 277-309 in D. J. Mladenoff and W. L. Baker, editors. Spatial modeling of forest landscape change: approaches and applications. Cambridge University Press, Cambridge, UK.

Baker, W. L., and T. T. Veblen. 1990. Spruce beetles and fires in the nineteenth-century subalpine forest of Western Colorado, U.S.A. Arctic and Alpine Research 22:65-80.

Barrows, J. S. 1951. Forest fires in the northern Rocky Mountains. USDA Forest Service Station Paper RM-28. Northern Rocky Mountain Forest and Range Experimental Station, Missoula, Montana, USA.

Bebi, P., F. Kienast, and W. Schönenberger. 2001. Assessing structures in mountain forests as a basis for investigating the forests' dynamics and protective function. Forest Ecology and Management 145:3-14.

Bessie, W. C., and E. A. Johnson. 1995. The relative importance of fuels and weather on fire behavior in subalpine forests. Ecology 76:747-762.

Boose, E. R., D. R. Foster, and M. Fluet. 1994. Hurricane impacts to tropical and temperate forest landscapes. Ecological Monographs 64:369-400.

Brito, J. C., E. G. Crespo, and O. S. Paulo. 1999. Modeling wildlife distribution: logistic regression vs. overlap analysis. Ecography 22:251-260.

Brown, J. K. 1975. Fire cycles and community dynamics in lodgepole pine forests. Pages $429-456$ in D. M. Baumgartner, editor. Management of lodgepole pine ecosystems. Washington State University Press, Corvallis, Oregon, USA.

Callaway, R. M., and F. W. Davis. 1993. Vegetation dynamics, fire, and the physical environment in Coastal Central California. Ecology 74:1567-1578.

Clements, F. E. 1910. The life history of lodgepole burn forests. United States Forest Service Bulletin 79. Government Printing Office, Washington, D.C., USA.

Cohen, J. 1960. A coefficient of agreement for nominal scales. Educational and Psychological Measurement 20: $37-46$.

del Moral, R., and L. C. Bliss. 1993. Mechanisms of primary succession: insights resulting from the eruption of Mount St. Helens. Advances in Ecological Research 24:1-66.

Despain, D. G., and R. E. Sellers. 1977. Natural fire in Yellowstone National Park. Western Wildlands 4:20-24.

ESRI. 2000. Arc 8. 0.2. Environmental Systems Research Institute, Redlands, California, USA.

Furyaev, V. V., R. W. Wein, and D. A. MacLean. 1983. Fire influences in Abies-dominated forests. Pages 221-234 in R. W. Wein and D. A. MacLean, editors. The role of fire in northern circumpolar ecosystems. John Wiley and Sons, London, UK.

Guisan, A., J. P. Theurillat, and F. Kienast. 1998. Predicting the potential distribution of plant species in an alpine environment. Journal of Vegetation Science 9:65-74.

Habeck, J. R., and R. W. Mutch. 1973. Fire-dependent forests in the northern Rockies. Quaternary Research 3:408-424. 
Hinds, T. E., F. G. Hawksworht, and R. W. Davidson. 1965 Beetle-killed Engelmann spruce: its deterioration in Colorado. Journal of Forestry 63:536-542.

Hopkins, A. D. 1909. Practical information on the Scolytid beetles of North American forests. I. Barkbeetles of the Genus Dendroctonus. USDA Bureau of Entomology Bulletin 83. U.S. Government Printing Office, Washington, D.C., USA.

Hosmer, D. W., Jr., and S. Lemeshow. 1989. Applied logistic regression. John Wiley and Sons, New York, New York, USA.

Kaluzny, S. P., S. Vega, T. P. Cardoso, and A. A. Shelly. 1997. S+ Spatial Statistics. User Manual. Springer-Verlag, New York, New York, USA.

Kipfmueller, K. F., and W. L. Baker. 2000. A fire history of a subalpine forest in southeastern Wyoming, USA. Journal of Biogeography 27:71-85.

Kitzberger, T., and T. T. Veblen. 1999. Fire-induced changes in northern Patagonian landscapes. Landscape Ecology 14: $1-15$.

Kitzberger, T., T. T. Veblen, and R. Villalba. 1995. Tectonic influences on tree growth in northern Patagonia, Argentina: the roles of substrate stability and climatic variation. Canadian Journal of Forest Research 25:1684-1696.

Knight, D. H. 1987. Parasites, lightning, and the vegetation mosaic in wilderness landscapes. Pages 59-83 in M. G. Turner, editor. Landscape heterogeneity and disturbance. Springer-Verlag, New York, New York, USA

Kulakowski, D. 2002. Interactions among natural disturbances in subalpine forests in northwestern Colorado. Dissertation. Department of Geography, University of Colorado, Boulder, Colorado, USA

Kulakowski, D., and T. Veblen. 2002. Influences of fire history and topography on the pattern of a severe wind blowdown in a Colarado subalpine forest. Journal of Ecology 90:806-819.

Malanson, G. P., and D. R. Butler. 1984. Avalanche paths as fuel breaks: implications for fire management. Journal of Environmental Management 19:229-238.

Mathsoft. 1999. S-Plus 2000. Professional edition for Windows. Release 2. Mathsoft, Seattle, Washington, USA

McCullough, D. G., R. A. Werner, and D. Neumann. 1998. Fire and insects in northern and boreal forest ecosystems of North America. Annual Review of Entomology 43:107127.

Mead, D. A. 1982. Assessing data quality in geographic information systems. Pages 51-62 in C. J. Johannsen and J. L. Sanders, editors. Remote sensing for resource management. Soil Conservation Society of America, Ankeny, Iowa, USA.

Östlund, L., O. Zackrisson, and A. L. Axelsson. 1997. The history and transformation of a Scandinavian boreal fores landscape since the 19th century. Canadian Journal of Forest Research 27:1198-1206.

Peet, R. K. 2000. Forests of the Rocky Mountains. Pages 63-102 in M. G. Barbour and W. D. Billings, editors. North American terrestrial vegetation. Second edition. Cambridge University Press, New York, New York, USA.

Radeloff, V. C. D., J. Mladenoff, and M. S. Boyce. 2000 Effects of interacting disturbances on landscape patterns: budworm defoliation and salvage logging. Ecological Applications 10:233-247.

Reid, M. 1989. The response of understory vegetation to major canopy disturbance in the subalpine forests of Colorado. Thesis. University of Colorado, Boulder, Colorado, USA.

Reynolds, K. M., and E. H. Holsten. 1994. Relative importance of risk factors for spruce beetle outbreaks. Canadian Journal of Forest Research 24:2089-2099.
Romme, W. H., and D. G. Despain. 1989. Historical perspective on the Yellowstone fires of 1988. BioScience 39: 695-699.

Romme, W. H., and D. H. Knight. 1981. Fire frequency and subalpine forest succession along a topographical gradient in Wyoming. Ecology 62:319-326.

Schmid, J. M., and R. H. Frye. 1976. Stand ratings for spruce beetles. USDA Forest Service Research Note RM-309. Rocky Mountain Forest and Range Experiment Station, Fort Collins, Colorado, USA.

Schmid, J. M., and R. H. Frye. 1977. Spruce beetle in the Rockies. USDA Forest Service General Technical Report RM-49. Rocky Mountain Forest and Range Experiment Station, Fort Collins, Colorado, USA.

Schmid, J. M., and T. E. Hinds. 1974. Development of spruce-fir stands following spruce beetle outbreaks. USDA Forest Service Research Paper RM-131. Rocky Mountain Forest and Range Experiment Station, Fort Collins, Colorado, USA.

Schmid, J. M., and J. Mata. 1996. Natural variability of specific forest insect populations and their associated effects in Colorado. USDA Forest Service General Technical Report RM-GTR-275. Rocky Mountain Forest and Range Experiment Station, Fort Collins, Colorado, USA.

Sheskin, M. 1985. Survey research for geographers. Association of American Geographers Resource Paper, Washington, D.C., USA.

Sibold, J. 2001. The forest fire regime of an upper montane and subalpine forest, Wild Basin, Rocky Mountain National Park. Thesis. University of Colorado, Boulder, Colorado, USA.

Skanes, H. M., and R. G. H. Bunce. 1997. Directions of landscape change (1741-1993) in Verestad, Sweden - characterized by multivariate analysis. Landscape and Urban Planning 38:61-75.

Sudworth, G. B. 1900. White River Plateau Timber Land Reserve. Pages 117-119 in Twentieth annual report of the United States Geological Survey, Part V. Forest Reserves. U.S. Government Printing Office, Washington, D.C., USA.

Turner, M., W. L. Baker, C. J. Peterson, and R. K. Peet. 1998 Factors influencing succession: lessons from large, infrequent natural disturbances. Ecosystems 1:511-523.

Turner, M. G., and V. H. Dale. 1998. Comparing large infrequent disturbances: what have we learned? Ecosystems 1:493-496.

Turner, M. G., W. W. Hargrove, R. H. Gardner, and W. H. Romme. 1994. Effects of fire on landscape heterogeneity in Yellowstone National Park, Wyoming. Journal of Vegetation Science 5:731-742.

USDA Forest Service. 1972. History of Routt National Forest. Available from Steamboat Springs (Colorado) Public Library 978.878814 HIS. Superintendent's Office, Laramie, Wyoming, USA.

Veblen, T. T. 2000. Disturbance patterns in southern Rocky Mountain forests. Pages 31-54 in R. L. Knight, F. W. Smith, S. W. Buskirk, W. H. Romme, and W. L. Baker, editors. Forest fragmentation in the southern Rocky Mountains. University Press of Colorado, Boulder, Colorado, USA.

Veblen, T. T., K. E. Hadley, E. M. Nel, T. Kitzberger, M. Reid, and R. Villalba. 1994. Disturbance regime and disturbance interaction in a Rocky Mountain subalpine forest. Journal of Ecology 82:125-135.

Veblen, T. T., K. S. Hadley, M. S. Reid, and A. J. Rebertus. 1991. The response of subalpine forests to spruce beetle outbreaks in Colorado. Ecology 72:213-234.

Wermelinger, B., M. K. Obrist, P. Duelli, and B. Forster. 1999. Development of the bark beetle (Scolytidae) fauna in windthrow areas in Switzerland. Mitteilungen der Schweizerischen Entomologischen Gesellschaft 72:209-220. 